\title{
Human Resource Information Systems and their Impact on Human Resource Management Strategies: A Field Study in Jordanian Commercial Banks
}

\author{
Dr. Khaled Mahmoud Al-Shawabkeh \\ Assistant Professor, Department of Management, World Islamic Sciences and Education University (WISE) \\ E-mail: kaled_high@yahoo.com
}

\begin{abstract}
Purpose - The purpose of this paper is to examine the impact of Human resource information system (HRIS) on Human Resource Management Strategies.Design/methodology/approach - The papers develops a research model based on current literature and then tests this model in (7) Jordanian Commercial Banks, selected from (13) banks. Statistics society consists of 185 persons from the higher and middle of management.Findings - The Study revealed that HRIS had a significant effect at level $(\mathrm{P} \leq 0.05)$ on Human Resource Management Strategies in Jordanian Commercial Banks.Research limitations/implications - This study could benefit from a large sample, from banks.Practical implications - The paper offers practical suggestions to the banking industry and management in general on how to manage the HRIS effects on Human Resource Management Strategies.Originality/value - This paper has tried to provide an inclusive understanding about the HRIS effects on Human Resource Management Strategies in the banking industry.

Keywords: Human Resource Information Systems (HRIS), Human Resource Management Strategies, Jordanian Commercial Banks.

\section{Introduction}

HRIS is defined as an "integrated system used to gather, store and analyze information regarding an organization's human resources' comprising of databases, computer applications, hardware and software necessary to collect, record, store, manage, deliver, present and manipulate data for human resources function" (Hendrickson, 2003). An HRIS can perform a number of functions from the simple storage and communication of information, to more complex transactions. As technology advances, the range of functions that an HRIS can undertake increases. The use of Human Resource Information Systems (HRIS) has been advocated as an opportunity for human resource (HR) professionals to become strategic partners with top management. The idea has been that HRIS would allow for the HR function to become more efficient and to provide better information for decision-making. The question remains whether HRIS has fulfilled its promise. (Beadles, Lowery \& Johns, 2005).
\end{abstract}

\section{Research Objectives}

This study explores the impact of (HRIS) on Human Resource Management Strategies in Jordanian Commercial Banks. The question to address in this study therefore is "what is the impact of HRIS on Human Resource Management Strategies in Jordanian Commercial Banks?”.

\section{Literature Review}

Some authors have proposed that the use of a HRIS would reduce HR costs by automating information and reducing the need for large numbers of HR employees; by helping employees to control their own personal information; and by allowing managers to access relevant information and data, conduct analysis, make decisions, and communicate with others without consulting an HR professional (Awazu \& Desouza, 2003; Ball, 2001). Ideally, with an appropriate use of HRIS, less people should be needed to perform administrative tasks such as record keeping and more time would be made available for HR managers to assist by providing data on a strategic level. Many of these authors believe the future to be bright for HRIS as it creates new paths for human resources and for the organizations that effectively use HRIS. One study even goes as far as to suggest that there is evidence that HRIS can improve shareholder value (Brown, 2002).

Human resource management (HRM) issues have been major concern for managers at all levels, because they all meet their goals through the efforts of others, which require the effective and efficient management of people (Dessler, 1999). The spacious array of HRM activities for example, planning, recruiting, selection, and training just to mention but few place enormous responsibilities on supervisors and managers alike. These embrace analyzing jobs, planning labor needs, selecting employees, orienting and training employees, managing compensation, communicating (which includes counseling and disciplining), and maintaining employee commitment. 
Actually HRIS is directed towards the HR department itself (Ruël, Bondarouk \& Looise, 2004), but the use of HRIS can provide a number of benefits not only to the HR function, but also line managers, and the wider organization(Parry, 2009). The use of HRIS has been advocated as an opportunity for human resource professionals to become strategic partners with top management. HRIS allow HR function to become more efficient and to provide better information for decision making (Beadles, Lowery \& Johns, 2005).

(Obeidat, 2012) concluded that Human resource information system functions were found to have a relationship with HRM functionalities. More specifically, it was found that strategic integration, forecasting and planning, human resources analysis, and communication and integration have no relationship with human resource functionalities. Whereas, it was found that performance development, knowledge management, and records and compliance as dimensions of human resources information systems have a relationship with human resources functionalities.

Kovach et al. (2002) listed several administrative and strategic advantages to using HRIS. Similarly, Beckers and Bsat (2002) pointed out at least five reasons why companies should use HRIS. These were that HRIS can:

(1) increase competitiveness by improving HR operations;

(2) produce a greater number and variety of HR-related reports;

(3) shift the focus of HR from the processing of transactions to strategic HRM;

(4) make employees part of HRIS; and

(5) reengineer the entire HR function of companies.

The existing literature on HRIS suggests that they have different impacts on HR across organizations, but provides little explanation for this variation. Early surveys suggested that HRIS were used predominantly to automate routine tasks and "to replace filing cabinets" (Martinsons, 1994). Ball (2001) concluded that HR had missed the strategic opportunity provided by HRIS. More recent research shows greater use of HRIS in support of strategic decision making by HR (Hussain et al., 2007). However, the extent to which HRIS is used in a strategic fashion differs across organizations, with the vast majority of organizations continuing to use HRIS simply to replace manual processing and to reduce costs (Bee \& Bee, 2002; Brown, 2002).

Many studies have shown that companies have started using sophisticated HRIS like training and development, performance management, compensation management and corporate communication (CedarCrestone, 2006; De Alwis, 2010; Saharan and Jafri, 2012).

(Kundu\& Kadian, 2012) intend to assess the applications of HRIS in human resource management (HRM) in companies operating in India. Primary data based on 544 respondents and 18 applications of HRIS in HRM were analyzed. Five factors from factor analysis were further analyzed. Respondents perceived "technical and strategic HRM" and "performance and reward management" as the most important factors for HRIS applications. The most frequent application of HRIS in organizations operating in India was found to be in "employee record", followed by "pay roll". Sophisticated HRIS applications i.e. "technical and strategic HRM", "performance and reward management" and "corporate communication" were also applied in organizations in India. ANOVA results showed that manufacturing and service companies differed significantly on all sophisticated HRIS applications. Mean scores showed that on all the sophisticated HRIS applications, service companies had significant edge over the manufacturing companies. However Indian and multinational companies did not differ significantly on any of the HRIS applications.

(Khera\& Gulati , 2012) explained in their study that Human resource information system (HRIS) is not new concept but it is recuperating day by day with changing environment. Its major role is in human resource planning (HRP) which itself a crucial activity in any organization. Ineffective HRP can lead to extra or fewer numbers of employees than needed. Both over and under number of employees can create crappy situations. HRIS helps in proper planning of human resources. This paper focuses on the role of HRIS in HRP. The research is empirical in nature as 127 respondents from top 7 IT companies (as per their market share) are taken to see the sights of the objectives. The survey is done with the assistance of the questionnaire. After investigation it is concluded that HRIS has various benefits but the foremost is HRIS stores ample data about the employees of the organizations that helps in escalating the snail's pace of HRP. HRIS also helps in the strategic activities of HR managers and more in training and development, succession planning, applicant tracking in recruitment and selection and manpower planning. While analyzing the overall contribution of HRIS in HRP it is concluded that HRIS identifies occupied and unoccupied positions in an organization very effectively and accurately.

(Beadles, Lowery \& Johns, 2005) mentioned in their study that various authors have advocated that the use of a Human Resource Information System (HRIS) should lead to valuable outcomes for the organization. Decreased costs, improved communication, and decreases in time spent on mundane activities should create an environment where in the Human Resources (HR) department would play a more strategic role in the organization. This study is an initial attempt to determine whether HRIS has reached these potential benefits. Based on responses from a sample of HR directors of from public universities we found that, while valuable, HRIS has not yet reached its full potential in this environment. 


\section{Hypotheses of the Study:}

HO1: There is no significant impact of Human Resource Information Systems on Human Resource Management Strategies in Jordanian Commercial Banks.

HO1.1: There is no significant impact of planning HR Systems on Human Resource Management Strategies in Jordanian Commercial Banks.

HO1.2: There is no significant impact of Staffing HR Systems on Human Resource Management Strategies in Jordanian Commercial Banks.

HO1.3: There is no significant impact of Training HR Systems on Human Resource Management Strategies in Jordanian Commercial Banks.

HO1.4: There is no significant impact of Assessment HR Systems on Human Resource Management Strategies in Jordanian Commercial Banks.

HO1.5: There is no significant impact of Compensation HR Systems on Human Resource Management Strategies in Jordanian Commercial Banks.

\section{Proposed Research Model:}

The study developed a conceptual framework that consists of two parts which simulate the study model as shown in figure (1). The first part of the model represents the HRIS Functions, while the second part represents on Human Resource Management Strategies.

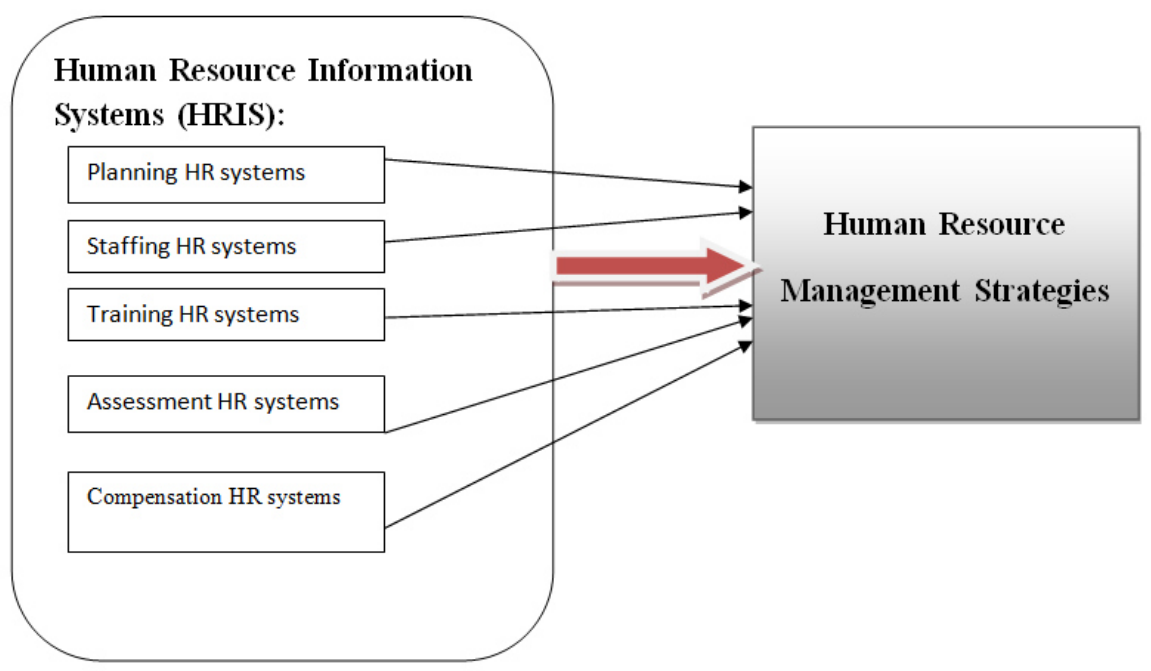

Source: Model prepared by the researcher.

\section{Methodology}

6.1 Purpose

This study is designed to investigate the impact of HRIS on Human Resource Management Strategies in Jordanian Commercial Banks. The results of this study should help Jordanian Commercial Banks managers determine the importance of HRIS in developing HRM Strategies.

\subsection{Populations and the study sample}

The target population of the study comprised of all Managers at high and middle level in Jordanian commercial banks. Indicated a total number of (13) bank. A simple random sampling of (7) banks was choosen. (190) questionnaires were distributed (185) surveys were included in the analysis.

6.3Unit of analysis

All Managers at high and middle level in Jordanian commercial banks.

6.4 Study Instrument

A questionnaire was used to collect the data. It included closed questions and was organized into three sections. Section one consisted of 4 questions concerning responder demographics. Section two focused on information about usage of HRIS. Section three focused on HRM strategies.

6.5Validity and Reliability

To ensure the validity of the instrument tool, the questionnaire was given to seven expert reviewers from Jordanian Universities. The reviewers displayed their constructive comments and suggestions, which were taken 
into consideration. However, the reliability test was conducted to Cronbach alpha correlation in each of the variables in the questionnaire. Cronbach alpha for Independent Variable $=(0.808)$, while for dependent Variable $=(0.814)$.

\section{Analysis and Results}

The following tools were used to test the hypothesis: frequencies, means, percentages and standard deviation were used as descriptive analysis to meet the study questions, while simple regression (enter) was used to test the main hypothesis and its branches.

H0 1: There is no significant impact of Human Resource Information Systems on Human Resource Management Strategies in Jordanian Commercial Banks.

Table 1: Simple regression (enter) of HRIS on Human resource management Strategies

\begin{tabular}{|c|c|c|c|c|c|c|c|c|}
\hline \multicolumn{4}{|c|}{ Coefficients } & \multicolumn{2}{c|}{ ANOVA/Analysis of variance } & \multicolumn{2}{c|}{ Model summary } \\
\hline sig & $\mathrm{t}$ & beta & & Sig & F & DF & $\mathbf{R}^{2}$ & R \\
\hline .0000 & 16.890 & 0.868 & HRIS & 0.000 & 126.872 & 1 & 0.610 & .868 \\
\hline
\end{tabular}

The value of $\mathrm{R} 2$ for HRIS model is $(0.61)$ and $(\mathrm{f}=126.872, \mathrm{P}=000)$ which explain $(61 \%)$ of variance in Human resource management Strategies. Therefore, HRIS was found to have a significant and positive effect on Human resource management Strategies, the regression coefficient for HRIS $(\beta=0.868, \mathrm{P}=000)$. Based on the result we can't accept the null hypothesis and accept the research hypothesis that indicates a significant impact of HRIS on Human resource management Strategies in Jordanian Commercial Banks at level of $(\mathrm{P} \leq 0.05)$

HO1.1: There is no significant impact of Planning Human Resource Information Systems on Human Resource Management Strategies in Jordanian Commercial Banks.

Table 2: Simple regression (enter) of Planning HR Systems on Human resource management Strategies.

\begin{tabular}{|c|c|c|l|l|c|c|c|c|}
\hline \multicolumn{3}{|c|}{ Coefficients } & \multicolumn{3}{c|}{ ANOVA/Analysis of variance } & \multicolumn{3}{c|}{ Model summary } \\
\hline sig & T & beta & & Sig & F & DF & $\mathbf{r}^{2}$ & r \\
\hline 0.000 & 13.528 & 0.705 & $\begin{array}{l}\text { Planning } \\
\text { HR systems }\end{array}$ & 0.000 & 182.999 & 1 & 0.500 & 0.705 \\
\hline
\end{tabular}

The value of $\mathrm{r} 2$ for Planning HR Systems model is $(0.50)$ and $(\mathrm{f}=182.999, \mathrm{P}=000)$ which explain $(50 \%)$ of variance in Human resource management Strategies. Therefore, Planning HR Systems were found to have a significant and positive effect on Human resource management Strategies, the regression coefficient for planning HRIS $(\beta=0.705, P=000)$. Based on the result we can't accept the null hypothesis and accept the research hypothesis that indicates a significant impact of Planning HR Systems on Human Resource Management Strategies in Jordanian Commercial Banks at level of $(\mathrm{P} \leq 0.05)$.

HO1.2: There is no significant impact of Staffing HR Systems on Human Resource Management Strategies in Jordanian Commercial Banks.

Table 2: Simple regression (enter) of Staffing HR Systems on Human resource management Strategies.

\begin{tabular}{|c|c|c|c|c|c|c|c|c|}
\hline \multicolumn{4}{|c|}{ Coefficients } & \multicolumn{2}{c|}{ ANOVA/Analysis of variance } & \multicolumn{2}{c|}{ Model summary } \\
\hline sig & $\mathrm{t}$ & beta & Sig & F & DF & $\mathbf{r}^{2}$ & $\mathrm{r}$ \\
\hline 0.000 & 9.578 & 0.588 & $\begin{array}{c}\text { Staffing HR } \\
\text { Systems }\end{array}$ & 0.000 & 97.114 & 1 & 0.338 & 0.588 \\
\hline
\end{tabular}

The value of $\mathrm{r} 2$ for Staffing HR Systems model is $(0.338)$ and $(\mathrm{f}=97.114, \mathrm{P}=000)$ which explain (33.8\%) of variance in Human resource management Strategies. Therefore, Staffing HR Systems were found to have a significant and positive effect on Human resource management Strategies, the regression coefficient for Staffing HR Systems $(\beta=0.588, P=000)$. Based on the result we can't accept the null hypothesis and accept the research hypothesis that indicates a significant impact of Staffing HR Systems on Human Resource Management Strategies in Jordanian Commercial Banks at level of $(\mathrm{P} \leq 0.05)$.

HO1.3: There is no significant impact of Training HR Systems on Human Resource Management Strategies in Jordanian Commercial Banks.

Table 3: Simple regression (enter) of Training HR Systems on Human resource management Strategies.

\begin{tabular}{|c|c|c|c|c|c|c|c|c|}
\hline \multicolumn{4}{|c|}{ Coefficients } & \multicolumn{2}{c|}{ ANOVA/Analysis of variance } & \multicolumn{2}{c|}{ Model summary } \\
\hline sig & $\mathrm{t}$ & beta & & Sig & F & DF & $\mathbf{r}^{2}$ & $\mathrm{r}$ \\
\hline 0.000 & 9.578 & 0.688 & $\begin{array}{c}\text { Training } \\
\text { HR Systems }\end{array}$ & 0.000 & 107.103 & 1 & 0.612 & 0.688 \\
\hline
\end{tabular}

The value of $\mathrm{r} 2$ for Training HR Systems model is $(0.612)$ and $(\mathrm{f}=107.103, \mathrm{P}=000)$ which explain $(61.2 \%)$ of variance in Human resource management Strategies. Therefore, Training HR Systems were found to have a significant and positive effect on Human resource management Strategies, the regression coefficient for Training HR Systems $(\beta=0.688, \mathrm{P}=000)$. Based on the result we can't accept the null hypothesis and accept the 
research hypothesis that indicates a significant impact of Training HR Systems on Human Resource Management Strategies in Jordanian Commercial Banks at level of $(\mathrm{P} \leq 0.05)$.

HO1.4: There is no significant impact of Assessment HR Systems on Human Resource Management Strategies in Jordanian Commercial Banks.

Table 4: Simple regression (enter) of Assessment HR Systems on Human resource management Strategies.

\begin{tabular}{|c|c|c|c|c|c|c|c|c|}
\hline \multicolumn{4}{|c|}{ Coefficients } & \multicolumn{3}{|c|}{ ANOVA/Analysis of variance } & \multicolumn{2}{|c|}{ Model summary } \\
\hline sig & $\mathrm{t}$ & beta & & Sig & $\mathrm{F}$ & DF & $\mathbf{r}^{2}$ & $\mathrm{r}$ \\
\hline 0.000 & 9.447 & 0.509 & $\begin{array}{l}\text { Assessment } \\
\text { HR Systems }\end{array}$ & 0.000 & 104.887 & 1 & 0.559 & 0.509 \\
\hline
\end{tabular}

The value of $\mathrm{r} 2$ for Assessment HR Systems model is $(0.559)$ and $(\mathrm{f}=104.887, \mathrm{P}=000$ ) which explain $(55.9 \%)$ of variance in Human resource management Strategies. Therefore, Assessment HR Systems were found to have a significant and positive effect on Human resource management Strategies, the regression coefficient for Assessment HR Systems $(\beta=0.509, \mathrm{P}=000)$. Based on the result we can't accept the null hypothesis and accept the research hypothesis that indicates a significant impact of Assessment HR Systems on Human Resource Management Strategies in Jordanian Commercial Banks at level of $(\mathrm{P} \leq 0.05)$.

HO1.5: There is no significant impact of Compensation HR Systems on Human Resource Management Strategies in Jordanian Commercial Banks.

Table 5: Simple regression (enter) of Compensation HR Systems on Human resource management Strategies.

\begin{tabular}{|c|c|c|c|c|c|c|c|c|}
\hline \multicolumn{4}{|c|}{ Coefficients } & \multicolumn{3}{c|}{ ANOVA/Analysis of variance } & \multicolumn{2}{c|}{ Model summary } \\
\hline sig & $\mathrm{t}$ & beta & Sig & F & DF & \multicolumn{2}{c|}{$\mathbf{r}^{2}$} & $\mathrm{r}$ \\
\hline 0.000 & 9.447 & 0.625 & $\begin{array}{c}\text { Compensation } \\
\text { HR Systems }\end{array}$ & 0.000 & 98.857 & 1 & 0.393 & 0.625 \\
\hline
\end{tabular}

The value of $\mathrm{r} 2$ for Compensation HR Systems model is (0.393) and ( $\mathrm{f}=98.857, \mathrm{P}=000)$ which explain $(39.3 \%)$ of variance in Human resource management Strategies. Therefore, Compensation HR Systems were found to have a significant and positive effect on Human resource management Strategies, the regression coefficient for Compensation HR Systems $(\beta=0.625, \mathrm{P}=000)$. Based on the result we can't accept the null hypothesis and accept the research hypothesis that indicates a significant impact of Compensation HR Systems on Human Resource Management Strategies in Jordanian Commercial Banks at level of $(\mathrm{P} \leq 0.05)$.

\section{Conclusions}

This study investigated the apparent impact of HRIS on HRM strategies in Jordanian Commercial Banks. The analysis of research results showed the overall consistency of findings with the model. This study makes a key contribution to the literature.

The study found a statistically significant impact at level $(\mathrm{P} \leq 0.05)$ of (planning HR Systems, Staffing HR Systems, Training HR Systems, Assessment HR Systems, and compensation HR Systems) on HRM Strategies in Jordanian Commercial Banks.

The study found a statistically significant impact at level $(\mathrm{P} \leq 0.05)$ of HRIS totally on HRM Strategies in Jordanian Commercial Banks.

\section{References}

Awazu, Yukika \& Desouza, Kevin C. (2003). Knowledge Management. HR Magazine. 48(11): 107.

Kovach, K.A. and Cathcart, C.E. Jr (1999), "Human resource information systems (HRIS): providing business with rapid data access, information exchange and strategic advantage", Public Personnel Management, 28(2): 275-281.

Kovach, K.A., Hughes, A.A., Fagan, P. and Maggitti, P.G. (2002), "Administrative and strategic advantages of HRIS", Employment Relations Today, 29(2): 43-8.

Ball, K. S. 2001. The use of human resource information systems: a survey. Personnel Review, 30(5-6): 677-693. Bee, F., \& Bee, R. 2002. Managing Information and Statistics. London: Chartered Institute of Personnel and Development.

Brown, D. 2002. E- HR - victim of unrealistic expectations. Canadian HR Reporter, 15(5).

Dessler G. (1999). Human Resources Management. In Canada seventh edition. Prentice-Hall Canada Inc. Scarborough, Ontario.

Hussain, Z., Wallace, J., \& Cornelius, N. E. 2007. The use and impact of human resource information systems on human resource management professionals. Information \& Management, 44(1): 74-89.

Martinsons, M. G. 1994. Benchmarking human resource information systems in Canada and Hong Kong. Information \& Management, 26(6): 305-316.

Kroenke, David M. (2013). Using MIS. Upper Saddle River, New Jersey, NJ: Pearson Education, Inc., 197. 
Obiedat, Bader. The Relationship between human resource information systems HRIS. Journal of Management Research, 4(4), 192- 211.

Hendrickson, A. R. (2003). Human resource information systems: Backbone technology of contemporary human resources, Journal of Labour Research, 24(3):381-394.

Parry, E. (2009). The benefits of using technology in human resources management.

In T. Coronas \& M. Oliva, Encyclopedia of human resources information systems: Challenges in E-HRM: 110 116.

Ruël, H., Bondarouk, T., \& Looise, J. K. (2004) E-HRM: Innovation or Irritation. An Explorative Empirical Study in Five Large Companies on Web-based HRM, Management Revue, 15(3: 364-381.

Beadles, N. A., Lowery, C. M., \& Johns, K. (2005). The impact of human resource information systems: An exploratory study in the public sector, Communication of the IIMA, 5(4): 39-46.

Kundu S.C., Kadian, Rajesh. (2012). Applications of HRIS in Human Resource Management in India: A Study. European Journal of Business and Management 4(21): 34- 41.

Khera, Shikha, Gulati, Karishma. (2012). Human Resource Information System and its impact on Human Resource Planning: A perceptual analysis of Information Technology companies. Journal of Business and Management (IOSRJBM) 3( 6 ): 06-13. 
The IISTE is a pioneer in the Open-Access hosting service and academic event management. The aim of the firm is Accelerating Global Knowledge Sharing.

More information about the firm can be found on the homepage:

http://www.iiste.org

\section{CALL FOR JOURNAL PAPERS}

There are more than 30 peer-reviewed academic journals hosted under the hosting platform.

Prospective authors of journals can find the submission instruction on the following page: http://www.iiste.org/journals/ All the journals articles are available online to the readers all over the world without financial, legal, or technical barriers other than those inseparable from gaining access to the internet itself. Paper version of the journals is also available upon request of readers and authors.

\section{MORE RESOURCES}

Book publication information: http://www.iiste.org/book/

Academic conference: http://www.iiste.org/conference/upcoming-conferences-call-for-paper/

\section{IISTE Knowledge Sharing Partners}

EBSCO, Index Copernicus, Ulrich's Periodicals Directory, JournalTOCS, PKP Open Archives Harvester, Bielefeld Academic Search Engine, Elektronische Zeitschriftenbibliothek EZB, Open J-Gate, OCLC WorldCat, Universe Digtial Library, NewJour, Google Scholar

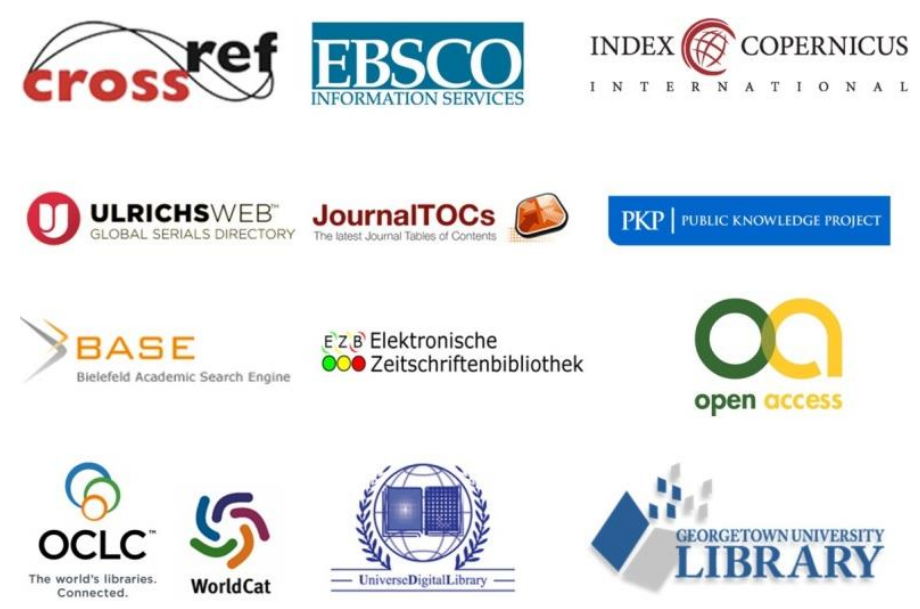

